\title{
EFFECT OF 16 WEEKS OF RESISTANCE TRAINING ON STRENGTH ENDURANCE IN MEN AND WOMEN
}

\section{EFEITO DE 16SEMANAS DE TREINAMENTO RESISTIDO SOBREARESISTENNCIA DE FORÇA EM HOMENSEMULHERES}

\author{
EFECTO DE 16 SEMANAS DE ENTRENAMIENTO RESISTIDO SOBRE LA RESISTENCIA DE FUERZA EN \\ HOMBRES Y MUJERES
}

\begin{abstract}
Introduction: Although resistance training (RT) can provide numerous benefits for both men and women, morphological, neuromuscular, metabolic, physiological, and behavioral differences between sexes may influence the magnitude of training responses. Objective: To analyze the impact of 16 weeks of progressive RT on strength endurance in untrained men and women. Methods: Twenty-eight men and 31 women (18-30 years) underwent a supervised RT program that was divided into two 8-week stages, 3 times per week on nonconsecutive days. The RT program was composed of exercises for different body segments (trunk, upper and lower limbs) that were performed with three sets of 8-12 repetitions maximum (RM), in 10 and 12 exercises, in the first and second stage, respectively. Strength endurance was assessed in 3 exercises (bench press, squat, and arm curl) and in a combination of these exercises through a protocol composed of 4 sets performed to failure with $80 \%$ of 1 -RM on the baseline, after 8 and 16 weeks of RT. Results: Group vs. time interactions $(p<0.05)$ were found for bench press ( $m e n=+28.3 \%$ vs. women $=+32.1 \%$ ), squat ( $m e n=+13.5 \%$ vs. women $=+32.7 \%$ ), and arm curl (men $=+20.2 \%$ vs. women $=+24.4 \%$ ) exercises, as well as in the set of all 3 exercises (men $=+18.4 \%$ vs. women $=+31.2 \%$ ). Conclusion: Our results suggest that 16 weeks of RT can improve strength endurance in both men and women, although higher gains are achieved by women. Level of evidence Il; Therapeutic study-Investigating treatment results.
\end{abstract}

Keywords: Physical fitness; Fatigue; Muscle strength; Resistance training.

\section{RESUMO}

Introdução: Embora o treinamento resistido (TR) possa proporcionar inúmeros benefícios tanto para homens quanto para mulheres, diferenças morfológicas, neuromusculares, metabólicas, fisiológicas e comportamentais entre os sexos podem influenciar na magnitude das respostas ao treinamento. Objetivo: Analisar o impacto de 16 semanas de TR progressivo sobre a resistência de força em homens e mulheres não treinados. Métodos: Foram submetidos a um programa de TR supervisionado em duas etapas de 8 semanas cada, três vezes por semana, em dias não consecutivos 28 homens e 31 mulheres (18 a 30 anos). O programa de TR foi composto por exercícios para os diferentes segmentos corporais (membros superiores, tronco e membros inferiores), que foram executados em três séries de oito a 12 repetições máximas (RM), em dez exercícios na primeira etapa e em 12 exercícios na segunda etapa de intervenção. A resistência de força foi avaliada em três exercícios (supino em banco horizontal, agachamento e rosca direta de bíceps) e na combinação entre eles, por meio de um protocolo composto por quatro séries executadas até a falha com 80\% de 1-RM, na linha de base, após 8 e 16 semanas de TR. Resultados: Interações grupo vs. tempo ( $p<0,05)$ foram encontradas para os exercícios supino (homens: $+28,3 \%$ vs. mulheres: $+32,1 \%$ ), agachamento (homens: $+13,5 \%$ vs. mulheres: $+32,7 \%$ ), rosca direta (homens: $+20,2 \%$ vs. mulheres: $+24,4 \%$ ), bem como no conjunto dos três exercícios (homens: $+18,4 \%$ vs. mulheres $+31,2 \%)$. Conclusão: Nossos resultados sugerem que 16 semanas de TR podem melhorar a resistência de força, tanto em homens quanto em mulheres, embora ganhos de maior magnitude sejam alcançados pelas mulheres. Nível de evidência Il; Estudo terapêutico - investigação dos resultados do tratamento.

Descritores: Aptidão física; Fadiga; Força muscular; Treinamento de resistência.

\section{RESUMEN}

Introducción: Aunque el entrenamiento resistido (ER) puede proporcionar innumerables beneficios tanto para hombres como para mujeres, diferencias morfológicas, neuromusculares, metabólicas, fisiológicas y comportamentales entre ambos sexos pueden influir en la magnitud de las respuestas al entrenamiento. Objetivo: Analizar el impacto de 16 semanas de ER progresivo sobre la resistencia de fuerza en hombres y mujeres no entrenados. Métodos: Veintiocho hombres y 31 mujeres (18 a 30 años) fueron sometidos a un programa de ER supervisado en dos etapas de ocho semanas cada una, tres veces por semana, en días no consecutivos. El programa de ER fue compuesto por ejercicios para los diferentes segmentos corporales (miembros superiores, tronco y miembros inferiores) que fueron ejecutados en tres series de 8-12 repeticiones máximas (RM), en 10 ejercicios en la primera etapa y 12 ejercicios en la segunda etapa de intervención. La resistencia de fuerza fue evaluada en tres ejercicios (press de banca, sentadilla y curl de bíceps) y en la combinación entre ellos, por medio de un protocolo compuesto por cuatro series ejecutadas 
hasta la falla con el 80\% de 1-RM, línea de base, después de ocho y 16 semanas de ER. Resultados: Interacciones grupo vs. tiempo $(p<0,05)$ fueron encontradas para los ejercicios press de banca (hombres $=+28,3 \%$ vs. mujeres $=+32,1 \%$ ), sentadilla (hombres $=+13,5 \%$ vs. mujeres $=+32,7 \%$ ), curl de biceps (hombres $=+20,2 \%$ vs. mujeres $=+24,4 \%$ ), asi como en el conjunto de los tres ejercicios (hombres $=+18,4 \%$ vs. mujeres $=+31,2 \%$ ). Conclusión: Nuestros resultados sugieren que 16 semanas de ER pueden mejorar la resistencia de fuerza, tanto en hombres como en mujeres, aunque los aumentos de mayor magnitud sean alcanzados por las mujeres. Nivel de evidencia Il; Estudio terapéutico -Investigación de los resultados del tratamiento.

Descriptores: Aptitud física, Fatiga; Fuerza muscular; Entrenamiento de resistencia.

\section{INTRODUCTION}

Increased strength endurance is related to improved fatigue resistance ${ }^{1,2}$ and can be acquired through regular resistance training (RT), a mode of physical exercise widely practiced by young men and women, especially to improve body esthetics and the ability to generate muscular strength, endurance, and power ${ }^{3}$. However, many of the responses induced by RT appear to be sex-dependent ${ }^{1-5}$ due to differences in muscular strength and mass, hormonal regulation, muscular architecture, energy storage, use of energy substrates, the muscular recovery process, and motor unit recruitment patterns, while other adaptive responses manifest themselves regardless of sex., 2,4,6-10

Salvador et al. ${ }^{1}$ revealed the presence of sexual dimorphism in strength endurance in women presenting a better response than men in multiple sets to failure, with $80 \%$ of one-repetition maximum (1-RM) after eight weeks of RT. On the other hand, the fatigue index improved similarly in both groups. These results were partially confirmed by Ribeiro et al., ${ }^{2}$ who found the presence of sexual dimorphism in fatigue resistance in exercises for the trunk (better result in women) but not in exercises for the upper limbs after 16 weeks of RT. Nonetheless, several studies that have compared physical performance between the sexes in different motor tasks revealed that women have greater strength endurance than men in different types of contraction, speed, position, age groups, and exercises. ${ }^{11-16}$

These findings are still not definitive due to the lack of a better methodological control of different factors that may interfere in responses to RT, such as the structure and duration of the training protocol, the subjects'level of physical fitness, and the forms of overload progression over time. Thus, this study aims to analyze the effect of 16 weeks of RT on strength endurance in men and women. Our hypothesis is that women will gain a greater magnitude of strength endurance than men in similar RT programs, as it appears that maximum strength gains and the magnitude of training load progression over time tend to be larger in women. ${ }^{1,2,10}$

\section{METHODS}

We developed this study over the course of 22 weeks. The participants were given two weeks to become familiar with the exercises in the RT program and for initial measurements and assessments (weeks 1 and 2). We designated eight weeks for RT in stage 1 (weeks 3 to 10). We dedicated two weeks for intermediate measurements and reassessments (weeks 11 and 12). Eight weeks were allocated for RT in stage 2 (weeks 13 to 20). Two weeks were set aside for final measurements and assessments (weeks 21 and 22). We analyzed the performance in 1-RM tests and strength endurance protocols in this study.

We selected the participants by reaching out to the public through posters and social media. We created a list containing the volunteers' personal information and subsequently scheduled individual interviews. During the interviews, several questions were used to analyze whether or not the candidate met the inclusion criteria established for this study. To be included, participants must be between the ages of 18 and 30 years; must not have had musculoskeletal injuries that prevented them from performing RT tests and sessions; must not have taken protein or creatine supplements or anabolic steroids; must not have been vegetarian; and must not have practiced RT regularly throughout the six months prior to the start of the study. We excluded participants who were absent from 15\% of the RT sessions and/or adhered to another exercise programs during the experiment. After the participants were informed of the procedures, they signed an informed consent form. This study was part of a longitudinal project that analyzed the effect of creatine supplementation on morphological and motor performance indicators in young men and women and has been approved by the Research Ethics Committee of Londrina State University (Report No. 028/2012), in accordance with the Declaration of Helsinki.

We measured body mass using a digital platform scale (Urano, PS 180A model; Porto Alegre, RS, Brazil), rounded to the nearest $0.1 \mathrm{~kg}$, and determined height using a wooden stadiometer, rounded to the nearest $0.1 \mathrm{~cm}$, according to the procedures described in the literature. ${ }^{17}$ We calculated body mass index (BMI) from the ratio between body mass $(\mathrm{kg})$ and the square of the height $(\mathrm{m})$.

We determined maximum strength by using 1-RM tests of three exercises: the bench press, squat, and arm curl. The 1-RM tests were preceded by a warm-up set (6 to 10 repetitions) with approximately $50 \%$ of the load to be tested in the first attempt in each exercise. The participant initiated their first attempt two minutes after warming up. Participants were instructed to try to complete two repetitions. After an interval of three to five minutes, there was a second attempt with a load greater or less than the one in the previous attempt, depending on whether the participant completed two repetitions or did not even complete one repetition, respectively. The same procedure was repeated on a third attempt. We recorded the maximum load that the individual could complete in one single voluntary muscular action as the 1-RM. The transition interval between exercises was five minutes. The form and technique of execution for each exercise were standardized and continuously monitored in an attempt to ensure the quality data. The participants always performed the tests at the three different stages of the study at the same time of the day and refrained from physical exercise during the weeks for the 1-RM tests. In an attempt to reduce the learning curve and establish test reproducibility in the three exercises, there were three familiarization sessions, separated by intervals of 48 to 72 hours, in the three assessment stages. ${ }^{18}$ The intraclass correlation coefficient (ICC) for each of the three exercises was greater than 0.98 . The sum of the total load lifted (TLL) in the three exercises was used as an indicator of overall strength.

A protocol to assess strength endurance was applied 48 to 72 hours after participants performed the 1-RM tests in the three exercises described above. The order in which the exercises were executed in this protocol was the same as the order adopted for the 1-RM tests. The 
protocol consisted of executing four sets of each exercise at 80\% of 1-RM to voluntary exhaustion. Participants were instructed to try to execute as many repetitions as possible in each of the sets until there was a functional inability to overcome the resistance. The rest interval between sets was two minutes, and the transition period between exercises was three to five minutes. The three exercises were preceded by a warm-up set (6-10 repetitions with approximately $50 \%$ of the load established for each exercise). We determined strength endurance by the total volume of effort (load X repetitions) and analyzed it separately in each of the three exercises and in combination by the total absolute volume (TAV).

The RT program was structured based on recommendations in the literature ${ }^{19}$ and conducted in three weekly sessions on alternate days. Physical education professionals supervised the participants individually in all training sessions. The RT protocol was divided into two stages of eight consecutive weeks, which were set apart by two-week intervals that were designated for reassessments and restructuring of the training programs. In both stages, the muscular hypertrophy process was the focus. We adopted an alternate setup per segment in the first stage and a pivotal setup in the second. The training program in the first stage included 10 exercises, while the second stage contained 12. Each exercise was executed in 3 sets of 8-12 RMs with fixed loads, except the exercises for the calf (15-20 RMs) and abdominal (30-50 RMs) muscle groups. The rest interval between sets was 60 to 90 seconds, while the interval between exercises was 120 to 180 seconds. The loads applied corresponded to $60-85 \%$ of 1-RM and were readjusted whenever the participant reached the maximum number of pre-established repetitions in all the sets for each exercise. We determined both the initial loads and the periodic readjustments to the loads applied by the repetition maximum weight test. ${ }^{9}$ The subjects were instructed not to perform any other type of regular systematic physical activity and to maintain their eating habits throughout the duration of the study so that the impact of RT could be assessed in isolation.

We used the Shapiro-Wilk test to analyze the distribution of data. We adopted the Levene test to examine the homogeneity of the variances and the Mauchly test to verify sphericity. In cases where sphericity was violated, the analyses were adjusted by using the Greenhouse-Geisser correction. We used the Student's t-test to compare the general characteristics of the groups at the baseline. We applied the analysis of covariance (ANCOVA) to compare the groups (men and women) over the training period (baseline, after 8 and 16 weeks of RT) and used the baseline measurements as covariates. We adopted the Bonferroni post hoc test to detect differences when $P<0.05$. We calculated the magnitude of the size of the differences by the effect size (ES). ${ }^{20}$ We considered an ES of 0.00-0.19 to be trivial and 0.20-0.49 to be small, while an effect size of 0.50-0.79 was moderate and $\geq 0.80$ was high. ${ }^{20}$ The data were stored and analyzed in SPSS for Windows, version 23.0 (SPSS Inc., Chicago, IL, USA), and STATISTICA for Windows, version 10.0 (StatSoft Inc., Tulsa, OK, USA).

\section{RESULTS}

The women presented lower values for body mass, height, and BMI than the men (Table 1).

Group vs. time interactions $(P<0.05)$ indicated increased muscular strength over the course of 16 weeks of RT (Table 2 ) in the bench press ( men $=+12.9 \%$ vs. women $=+24.1 \%)$, squat (men $=+26.2 \%$ vs. women $=+23.6 \%)$, arm curl (men $=+14.8 \%$ vs. women $=+21.5 \%)$, and TLL (men $=+19.9 \%$ vs. women $=+23.3 \%)$. Increases in muscular strength occurred progressively and were identified within the first eight weeks of the intervention $(P<0.05)$. The muscular strength gains resulted in a high ES for both men and women in all the variables we analyzed (0.87 - 1.54), except for men in the bench press exercise (moderate effect).
Table 1. Participants' physical characteristics at the baseline.

\begin{tabular}{c|c|c|c|c}
\hline Variable & $\begin{array}{c}\text { Men } \\
(\mathbf{n = 2 8})\end{array}$ & $\begin{array}{c}\text { Women } \\
(\mathbf{n = 3 1 )}\end{array}$ & $\begin{array}{c}\text { All } \\
(\mathbf{n = 5 9 )}\end{array}$ & 95\% Cl \\
\hline Age (years) & $22.8 \pm 3.0$ & $20.2 \pm 2.9$ & $21.5 \pm 3.2$ & $20.7-22.3$ \\
\hline Body mass $(\mathrm{kg})$ & $73.0 \pm 9.3$ & $57.9 \pm 7.9$ & $65.0 \pm 11.4$ & $62.1-68.0$ \\
\hline Height $(\mathrm{cm})$ & $179.4 \pm 5.2$ & $165.2 \pm 5.5$ & $171.9 \pm 8.9$ & $169.6-174.2$ \\
\hline BMl $\left(\mathrm{kg} / \mathrm{m}^{2}\right)$ & $22.7 \pm 2.7$ & $21.2 \pm 2.7$ & $21.9 \pm 2.8$ & $21.2-22.6$ \\
\hline
\end{tabular}

Note. The results are expressed as mean \pm standard deviation, $95 \% \mathrm{Cl}=95 \%$ confidence interval, $\mathrm{BMI}=$ body mass index

Table 2. Loads lifted by men and women in one-repetition maximum (1-RM) tests at the baseline and after 8 and 16 weeks of resistance training.

\begin{tabular}{|c|c|c|c|c|c|}
\hline Variable & $\begin{array}{c}\text { Men } \\
(n=28)\end{array}$ & $\begin{array}{l}\text { Women } \\
(n=31)\end{array}$ & Effects & $F$ & $P$ \\
\hline Bench press (kg) & & & ANCOVA & & \\
\hline Baseline & $73.8 \pm 16.8$ & $28.6 \pm 6.6$ & Grupo & 2.72 & 0.11 \\
\hline After 8 weeks & $78.7 \pm 17.0^{*}$ & $33.2 \pm 5.7^{*}$ & Tempo & 16.65 & $<0.001$ \\
\hline After 16 weeks & $83.3 \pm 16.8^{*} \S$ & $35.5 \pm 6.2^{*} \S$ & Grupo x Tempo & 3.35 & $<0.05$ \\
\hline ES & +0.57 & +1.08 & & & \\
\hline Squat (kg) & & & ANCOVA & & \\
\hline Baseline & $113.5 \pm 17.3$ & $74.7 \pm 16.5$ & Grupo & 3.14 & 0.08 \\
\hline After 8 weeks & $130.0 \pm 20.1^{*}$ & $86.3 \pm 18.3^{*}$ & Tempo & 3.85 & $<0.05$ \\
\hline After 16 weeks & $143.2 \pm 21.2^{*} \S$ & $92.3 \pm 19.5^{*} \S$ & Grupo x Tempo & 5.37 & $<0.05$ \\
\hline ES & +1.54 & +0.97 & & & \\
\hline Arm curl (kg) & & & ANCOVA & & \\
\hline Baseline & $41.3 \pm 7.1$ & $22.3 \pm 3.9$ & Grupo & 2.68 & 0.11 \\
\hline After 8 weeks & $44.6 \pm 7.4^{*}$ & $25.4 \pm 4.1^{*}$ & Tempo & 18.30 & $<0.001$ \\
\hline After 16 weeks & $47.4 \pm 7.0^{*} \S$ & $27.1 \pm 3.8^{*}$ & Grupo x Tempo & 6.15 & $<0.01$ \\
\hline ES & +0.87 & +1.25 & & & \\
\hline TLL (kg) & & & ANCOVA & & \\
\hline Baseline & $228.5 \pm 37.1$ & $125.6 \pm 24.9$ & Grupo & 1.78 & 0.19 \\
\hline After 8 weeks & $253.2 \pm 40.8^{*}$ & $144.9 \pm 25.6^{*}$ & Tempo & 11.28 & $<0.001$ \\
\hline After 16 weeks & $273.9 \pm 41.0^{*} \S$ & $154.9 \pm 26.9^{*} \S$ & Grupo x Tempo & 5.06 & $<0.05$ \\
\hline ES & +1.16 & +1.13 & & & \\
\hline
\end{tabular}

Note. TLL = total load lifted in the sum of the three exercises, ES = effect size. The results are expressed as mean \pm standard deviation. ${ }^{*} P<0.05$ vs. Baseline and $\S \mathrm{P}<0.05$ vs. After 8 weeks.

We found a progressive improvement in strength endurance in both groups (Table 3), with significant differences after eight weeks of RT $(P<0.05)$. Group vs. time interactions $(P<0.05)$ were identified in the bench press ( $m e n=+28.3 \%$ vs. women $=+32.1 \%$ ), squat (men $=+13.5 \%$ vs. women $=+32.7 \%$ ), arm curl (men $=+20.2 \%$ vs. women $=+24.4 \%$ ), and TAV (men $=+18.4 \%$ vs. women $=+31.2 \%$ ). Improved strength endurance resulted in an ES of high magnitude (0.84 - 1.27), except for men in the squat exercise (small effect) and in TAV (moderate effect).

\section{DISCUSSION}

The main finding of this study was that the increase in strength endurance brought on by 16 weeks of RT correlated with the improvement in maximum strength in both men and women. However, the gains observed in women were higher than those found in men, confirming our hypothesis of the presence of sexual dimorphism for both strength endurance and maximum strength.

The increase in muscular strength caused by RT in men and women under the same RT protocol has already been documented in previous studies, lasting eight ${ }^{1,6}$ and sixteen weeks. 2,5,10 Nevertheless, to our knowledge, this is the first study that analyzed the behavior of maximum strength and strength endurance on different body segments based on sex, allowing us to observe the behavior of these variables after eight and sixteen weeks. Therefore, we examined the responses by considering 
Table 3. Total volume (loads $x$ repetitions) obtained by men and women under protocol of four sets at $80 \%$ of 1-RM to failure at the baseline and after 8 and 16 weeks of resistance training.

\begin{tabular}{|c|c|c|c|c|c|}
\hline Variable & $\begin{array}{c}\text { Men } \\
(n=28)\end{array}$ & $\begin{array}{l}\text { Women } \\
(n=31)\end{array}$ & Effects & $F$ & $P$ \\
\hline Bench press $(\mathrm{kg})$ & & & ANCOVA & & \\
\hline Baseline & $1263.2 \pm 483.6$ & $426.2 \pm 105.2$ & Grupo & 80.16 & $<0.001$ \\
\hline After 8 weeks & $1493.4 \pm 313.5^{*}$ & $507.0 \pm 130.6^{*}$ & Tempo & 66.11 & $<0.001$ \\
\hline After 16 weeks & $1620.8 \pm 347.8^{*}$ & $562.9 \pm 126.5^{*}$ & $\begin{array}{l}\text { Grupo x } \\
\text { Tempo }\end{array}$ & 44.62 & $<0.001$ \\
\hline ES & +0.85 & +1.27 & & & \\
\hline Squat (kg) & & & ANCOVA & & \\
\hline Baseline & $2809.2 \pm 804.2$ & $1299.7 \pm 282.0$ & Grupo & 6.24 & $<0.05$ \\
\hline After 8 weeks & $2993.3 \pm 828.0^{*}$ & $1638.5 \pm 463.0^{*}$ & Tempo & 11.58 & $<0.001$ \\
\hline After 16 weeks & $3189.4 \pm 936.3^{*}$ & $1724.5 \pm 509.0^{*}$ & $\begin{array}{l}\text { Grupo x } \\
\text { Tempo }\end{array}$ & 3.98 & $<0.05$ \\
\hline$E S$ & +0.44 & +1.03 & & & \\
\hline Arm curl (kg) & & & ANCOVA & & \\
\hline Baseline & $572.3 \pm 153.8$ & $347.1 \pm 85.9$ & Grupo & 49.16 & $<0.001$ \\
\hline After 8 weeks & $664.2 \pm 120.1^{*}$ & $420.9 \pm 79.2^{*}$ & Tempo & 69.39 & $<0.001$ \\
\hline After 16 weeks & $687.9 \pm 121.3^{*}$ & $431.8 \pm 70.9^{*}$ & $\begin{array}{c}\text { Grupo x } \\
\text { Tempo }\end{array}$ & 26.09 & $<0.001$ \\
\hline ES & +0.84 & +0.88 & & & \\
\hline TAV $(\mathrm{kg})$ & & & ANCOVA & & \\
\hline Baseline & $4644.8 \pm 1130.6$ & $2072.9 \pm 408.7$ & Grupo & 17.51 & $<0.001$ \\
\hline After 8 weeks & $5150.9 \pm 961.8^{*}$ & $2566.4 \pm 538.4^{*}$ & Tempo & 20.45 & $<0.001$ \\
\hline After 16 weeks & $5498.1 \pm 1066.9^{*}$ & $2719.6 \pm 593.4^{*}$ & $\begin{array}{c}\text { Grupo x } \\
\text { Tempo }\end{array}$ & 9.52 & $<0.001$ \\
\hline ES & +0.78 & +1.27 & & & \\
\hline
\end{tabular}

Note. $E S=$ effect size, $T A V=$ total absolute volume in the sum of the three exercises. The results are expressed as mean \pm standard deviation. ${ }^{*} P<0.05$ vs. Baseline.

the training progression used in both periods. Our results indicated the presence of sexual dimorphism for both maximum strength and strength endurance in different body segments.

The gains in muscular strength made by untrained individuals in the first weeks of RT have been associated mainly with neural adaptations, with a discrete contribution to the hypertrophy process. ${ }^{21}$ The increased cross-sectional area of the muscle fibers seems to contribute more markedly to the increase in strength production only after six to eight weeks of training. ${ }^{22}$ Some of the potential mechanisms associated with muscular strength gains identified in the first weeks of RT include the increased recruitment of high-threshold motor units, the increased frequency of motor unit discharges and synchronization, better coordination between agonist and antagonist muscles, and/or reduction in antagonist muscle coactivation. ${ }^{23}$ In this study, the greatest strength gains occurred in the first eight weeks of the intervention for both sexes. However, Lemmer et al..$^{24}$ evidenced an increase in strength only in women after 9 weeks of unilateral strength training. This result suggests that neural responses may be processed with differentiated motor unit recruitment patterns in men and women. This fact may at least partially explain the greater gains in maximum strength found in the women of this study for the three exercises.

Additionally, Martel et al..$^{25}$ identified an increase in the proportion of type I fibers and a simultaneous decrease in type IIX fibers in women after 9 weeks of RT. This finding strengthens the hypothesis that in short intervention periods, neural adaptations play a more important role than muscular hypertrophy for strength gains and, probably, strength endurance, especially in women. The results for strength endurance in our study confirmed this hypothesis, since the better responses were found in women. Notwithstanding, the absence of objective measures for neural and hypertrophic components does not allow for a more consistent analysis of the potential mechanisms involved in the differences observed between the sexes.

Given that the percentage of fast twitch fibers is proportionally higher in men and that the hypertrophy process contributes more emphatically to muscular strength gains in longer training periods, ${ }^{26}$ greater muscular strength gains would be expected from men according to the second stage of our experiment. This hypothesis was confirmed only for the squat exercise. On the other hand, in both stages of this study, women demonstrated greater gains in maximum strength and strength endurance in exercises for the trunk and upper limbs. A possible explanation for these results may be that the muscular strength recorded for the women was lower than that for the men at the beginning of the study in the 1-RM tests for the bench press (39\%) and arm curl (54\%). It is already well established in the literature that initial strength levels might influence adaptations induced by RT.22 It is noteworthy that the higher concentrations of intramuscular creatine that are generally found in women ${ }^{27}$ may favor improved physical performance by increasing the rate of strength generation and reducing the fatigue index and recovery time for intermittent efforts, due to the increase in the ATP synthesis rate. ${ }^{28}$ This hypothesis is supported in this study by the greater gains in muscular strength and strength endurance found in women.

Several points of this study deserve attention. The protocol we adopted allowed us to examine men and women under similar training conditions. Moreover, the load adjustments were continuous and based on the participants' individual progress over the course of the RT sessions, which allowed us to maintain the intensity throughout the intervention. In addition, participants were individually supervised, which enabled standardized execution as well as verbal encouragement (external motivation), factors that differentiate responses from supervised and unsupervised training. ${ }^{29}$ We also note that restructuring training after eight weeks, with changes in the order of execution and an increased number of exercises, enabled new adaptive responses, thereby reducing the possibility of the plateau effect, which is quite typical of training protocols that do not adopt progression models. ${ }^{19}$ Finally, the performance measure in 1-RM tests involved a familiarization process prior to the tests in an attempt to ensure the technical quality of their execution and the reliability of the records in each exercise. ${ }^{18}$

Conversely, important limitations of this study should not be overlooked. Although the participants were instructed to maintain their eating habits and habitual physical activity level, these variables were not controlled over the course of the study. The lack of systematic control of these variables may at least partially compromise the adaptive responses caused by RT, as these factors may influence different components of body composition, especially fat mass and fat-free mass, as well as metabolism, thus affecting the magnitude of muscular strength and endurance gains. Moreover, women's menstrual cycles, a potential confounding factor, were not controlled. Additionally, we did not obtain any metabolic, physiological, or psychobiological information along with the motor performance measures, making it impossible to analyze the potential mechanisms involved with the responses found. Finally, our findings should not be applied to other intervention duration periods or to other populations, including participants of different age groups and initial fitness levels, as various responses to RT may be influenced by such factors. ${ }^{12,30}$

This study's main practical application is that RT should be recommended to improve muscular strength and strength endurance, especially for women. Despite having lower rates of muscular strength and strength endurance than men, women appear to be just as or even more responsive to this type of training than men, considering similar 
age and physical fitness levels. It is noteworthy that muscular strength and strength endurance are closely related to daily living activities and tend to directly or indirectly influence the level of habitual physical activity and quality of life (autonomy and self-esteem).

\section{CONCLUSION}

Our results suggest that 16 weeks of RT may improve strength endurance in both men and women who have not practiced RT for at least six months, although women obtain greater gains. Furthermore, increased strength endurance appears to correlate with improved maximum strength.

\section{ACKNOWLEDGMENTS}

The authors would like to thank the participants for their valuable cooperation throughout the study and the National Council for Scientific and Technological Development (CNPq) for the Research Productivity Scholarship granted to ESC. This study was partially funded by CNPq and Araucária Foundation for the Support of Scientific and Technological Development of Paraná

All authors declare no potential conflict of interest related to this article

AUTHORS' CONTRIBUTIONS: Each author made significant individual contributions to this manuscript. LTC (0000-0002-8387-6176)*: literature review, data collection, supervision of training, statistical analysis and data interpretation, writing, critical review of the manuscript; ESC (0000-0001-9016-8779)*: conception of the study, statistical analysis and data interpretation, writing, critical review of the manuscript; ECAS (0000-0002-7116-4382)*: literature review, data collection, writing, critical review of the manuscript; AA (0000-00029562-7230)*: data collection, supervision of training, critical review of the manuscript; MCCT (0000-0002-2775-051X)*: data collection, supervision of training, critical review of the manuscript; DRPS (0000-0003-3995-4795)*: conception of the study, statistical analysis and data interpretation, writing, and critical review of the manuscript. All authors approved the final version of the manuscript. ${ }^{*} \mathrm{ORCID}$ (Open Researcher and Contributor ID).

\section{REFERENCES}

1. Salvador EP, Dias RM, Gurjão AL, Avelar A, Pinto LG, Cyrino ES. Effect of eight weeks of strength training on fatigue resistance in men and women. Isokinet Exerc Sci. 2009;17(2):101-6.

2. Ribeiro AS, Avelar A, Schoenfeld BJ, Trindade MC, Ritti-Dias RM, Altimari LR, et al. Effect of 16 weeks of resistance training on fatigue resistance in men and women. J Hum Kinet. 2014;42(1):165-74.

3. Ribeiro AS, Avelar A, Schoenfeld BJ, Fleck SJ, Souza MF, Padilha CS, et al. Analysis of the training load during a hypertrophy-type resistance training programme in men and women. Eur J Sport Sci. 2015;15(4):256-64.

4. Salvador EP, Cyrino ES, Gurjão AL, Ritti Dias RM, Nakamura FY, Oliveira AR. A comparison of motor performance between men and women in multiple sets of weight exercises. Rev Bras Med Esporte. 2005;11(5):242-5.

5. Ribeiro AS, Avelar A, Nascimento MA, Mayhew JL, Campos Filho MG, Eches EH, et al. What is the actual relative intensity of a resistance training program for men and women? Isokinet Exerc Sci. 2014;22(3):217-24.

6. Ritti Dias RM, Cyrino ES, Salvador EP, Nakamura FY, Pina FL, Oliveira AR. Impact of eight weeks of weight training on muscle strength in men and women. Rev Bras Med Esporte. 2005;11(4):224-8.

7. Barquilha G, Ribeiro AS, Silva DR, Oliveira JC, Azevedo PH, Cyrino ES. Efeito de diferentes intervalos de recuperação sobre a resistência de força em indivíduos de ambos os sexos. Rev Educ Fis UEM. 2013;24(2):261-8.

8. Ribeiro AS, Avelar A, Schoenfeld BJ, Ritti Dias RM, Altimari LR, Cyrino ES. Resistance training promotes increase in intracellular hydration in men and women. Eur J Sport Sci. 2014;14(6):578-85.

9. Ribeiro AS, Avelar A, dos Santos L, Silva A, Gobbo LA, Schoenfeld BJ, et al. Hypertrophy-type resistance training improves phase angle in young adult men and women. Int J Sports Med. 2017;38(1):35-40.

10. Ribeiro AS, Campos Filho MG, Avelar A, dos Santos L, Achour Júnior A, Aguiar AF, et al. Effect of resistance training on flexibility in young adult men and women. Isokinet Exerc Sci. 2017;25(2):149-55.

11. Hunter SK, Enoka RM. Sex differences in the fatigability of arm muscles depends on absolute force during isometric contractions. J Appl Physiol. 2001;91(6):2686-94.

12. Kent-Braun JA, Ng AV, Doyle JW, Towse TF. Human skeletal muscles responses vary with age and gender during fatigue due to incremental isometric exercise. J Appl Physiol (1985). 2002;93(5):1813-23.

13. Pincivero DM, Gandaio CM, Ito Y. Gender-specific knee extensor torque, flexor torque, and muscle fatigue responses during maximal effort contractions. Eur J Appl Physiol. 2003;89(2):134-41.

14. Hunter SK, Critchlow A, Shin IS, Enoka RM. Men are more fatigable than strength-matched women when performing intermittent submaximal contractions. J Appl Physiol(1985). 2004;96(6):2125-32.
15. Clark BC, Collier SR, Manini TM, Ploutz-Snyder LL. Sex differences in muscle fatigability and activation patterns of the human quadriceps femoris. Eur J Appl Physiol. 2005;94(1-2):196-206.

16. Hunter SK, Butler JE, Todd G, Gandevia SC, Taylor JL. Supraspinal fatigue does not explain the sex difference in muscle fatigue of maximal contractions. J Appl Physiol (1985). 2006;101(4):1036-44.

17. Gordon CC, Chumlea WC, Roche AF. Stature, recumbent length, and weight. In: Lohman TG, Roche AF, Martorell R. (eds). Anthropometric standardizing reference manual. Champaign: Human Kinetics; 1988. p.3-8.

18. Ribeiro AS, do Nascimento MA, Salvador EP, Gurjão AL, Avelar A, Ritti-Dias RM, et al. Reliability of one-repetition maximum test in untrained young adult men and women. Isokinet Exerc Sci. 2014;22(3):175-82.

19. American College of Sports Medicine. American College of Sports Medicine position stand. Progression models in resistance training for healthy adults. Med Sci Sport Exerc. 2009;41(3):687-708.

20. Cohen J. Statistical power analysis for the behavioral sciences. Hillsdale: Lawrence Erlbaum Associate; 1988.

21. Schoenfeld BJ. The mechanisms of muscle hypertrophy and their application to resistance training. Strength Cond Res. 2010;24(10):2857-72.

22. Cormie P, McGuigan MR, Newton RU. Influence of strength on magnitude and mechanisms of adaptation to power training. Med Sci Sports Exerc. 2010;42(8):1566-81.

23. Gabriel DA, Kamen G, Frost G. Neural adaptations to resistive exercise: mechanisms and recommendations for training practices. Sports Med. 2006;36(2):133-49.

24. Lemmer JT, Hurlbut DE, Martel GF, Tracy BL, Ivey FM, Metter EJ, et al. Age and gender responses to strength training and detraining, Med Sci Sports Exerc. 2000;32(8):1505-12.

25. Martel GF, Roth SM, Ivey FM, Lemmer JT, Tracy BL, Hurlbut DE, et al. Age and sex affect human muscle fibre adaptations to heavy resistance strength training. Exp Physiol. 2006;91(2):457-64.

26. Sale DG, MacDougall JD, Alway SE, Sutton JR. Voluntary strength and muscle characteristics in untrained men and women and male bodybuilders. J Appl Physiol 1985. 1987;62(5):1786-93.

27. Fosberg AM, Nilsson E, Werneman J, Bergströn J, Hultman E. Muscle composition in relation to age and sex. Clin Sci (Lond). 1991;81(2):249-56.

28. Lanhers C, Pereira B, Naughton G, Trousselard M, Lesage FX, Dutheil F. Creatine supplementation and upper limb strength performance: a systematic review and meta-analysis. Sports Med. 2017;47(1):163-73.

29. Mazzetti SA, Kraemer WJ, Volek JS, Duncan ND, Ratamess NA, Gómez AL, et al. The influence of direct supervision of resistance training on strength performance. Med Sci Sport Exerc. 2000;32(6):1175-84.

30. Damas F, Phillips S, Vechin FC, Ugrinowitsch C. A review of resistance training-induced changes in skeletal muscle protein synthesis and their contribution to hypertrophy. Sports Med. 2015;45(6):801-7. 